\title{
Studies on cupulate species of Helvella
}

\author{
HARRI HARMAJA
}

\begin{abstract}
HARMAJA, H. 1979: Studies on cupulate species of Helvella. - Karstenia 19: $33-45$.

The paper treats the taxonomy and distribution of two very closely related species in sect. Acetabulum Diss., Helvella costifera Nannf. s. str. and H. hyperborea Harmaja (Pezizales). $H$. hyperborea has generally darker pigmentation and less prominent ribs on the cup exterior and it occurs in late summer and autumn, usually in completely natural habitats, in boreal and alpine areas of Finland, Sweden, Norway and Iceland. $H$. costifera mainly fruits in summer, and occurs in man-influenced sites, preferring lower latitudes and altitudes.

Descriptions are given of the most important characters distinguishing four species in sect. Leucomelaenae Diss., $H$. leucomelaena (Pers.) Nannf., H. confusa Harmaja, $H$. pedunculata Harmaja and $H$. oblongispora Harmaja. $H$. pedunculata is reported from Finland and Norway, and $H$. oblongispora from Sweden, Norway, the Federal Republic of Germany, and Austria.

The new species Helvella ulvinenii Harmaja (sect. Acetabulum) is described from Finnish Lapland. The first record of $H$. dryadophila Harmaja from Finland and two new localities for Norway are reported. Acetabula murina Zeller, described from Oregon, is found to be a younger synonym of $H$. solitaria Karst. (H. queletii Bres.). The specific status of $H$. verruculosa (Sacc.) Harmaja (Peziza verruculosa Berk. \& Curt.), known only from the Bering Straits (U.S.S.R.), is substantiated.
\end{abstract}

Harri Harmaja, Botanical Museum, University of Helsinki, Unioninkatu 44, SF00170 Helsinki 17, Finland

\section{Helvella costifera and $H$. hyperborea}

In the autumns of 1970-1972, in Kuusamo, N.E. Finland, my attention was attracted by a Helvella which I suspected to be the dark northern form of $H$. acetabulum (St-Am.) Quél., as presented by Dissing (1966). Dissing also reported similar deviating collections of the closely related $H$. costifera Nannf., and later I associated my fungus with this species rather than with $H$. acetabulum. Some of Dissing's (1966) specific concepts appear to be collective and I recently segregated some dark-coloured, late-fruiting, arctic-alpine species from $H$. acetabulum sensu Dissing (Harmaja 1976c, 1977b). The 'dark northern form' of $H$. costifera, known only from Fennoscandia and Iceland, also proved to be specifically distinct, and I briefly described it as $H$. hyperborea Harmaja (Harmaja 1978). In the present paper it will be treated more fully.

All the material filed as $H$. costifera in the main Nordic herbaria was examined. During my revision of the $H$. acetabulum group in Fennoscandia, I also saw most of the material deposited as $H$. acetabulum from that and other northern regions. Almost all the specimens of $H$. costifera, including several from outside the Nordic countries, proved to represent either $H$. costifera s.str. or $H$. hyperborea. Two specimens which had been published (Dissing 1966) as $H$. costifera, turned out to be $H$. oblongispora Harmaja (see further) and the following two $H$. acetabulum: 1) Sweden, Jämtland, Östersund, 14.VII.1902 Andersson (S); 2) Greenland, Søndre Strømfjord, Hassels Fjeld, in loess in Salix scrub, 28.VII.1947 Lange 171 (C). In the latter case the original identification (Lange 1957) thus proved correct. (It is curious that three specimens of $H$. acetabulum s.str. are now known from Greenland (see also Harmaja 1977b: 53), while none of the arctic-alpine segregates of that species and neither of the species of the H. costifera group have so far been found there.)

On the other hand, four specimens filed and published as $H$. acetabulum turned out to belong to the $H$. costifera group. 


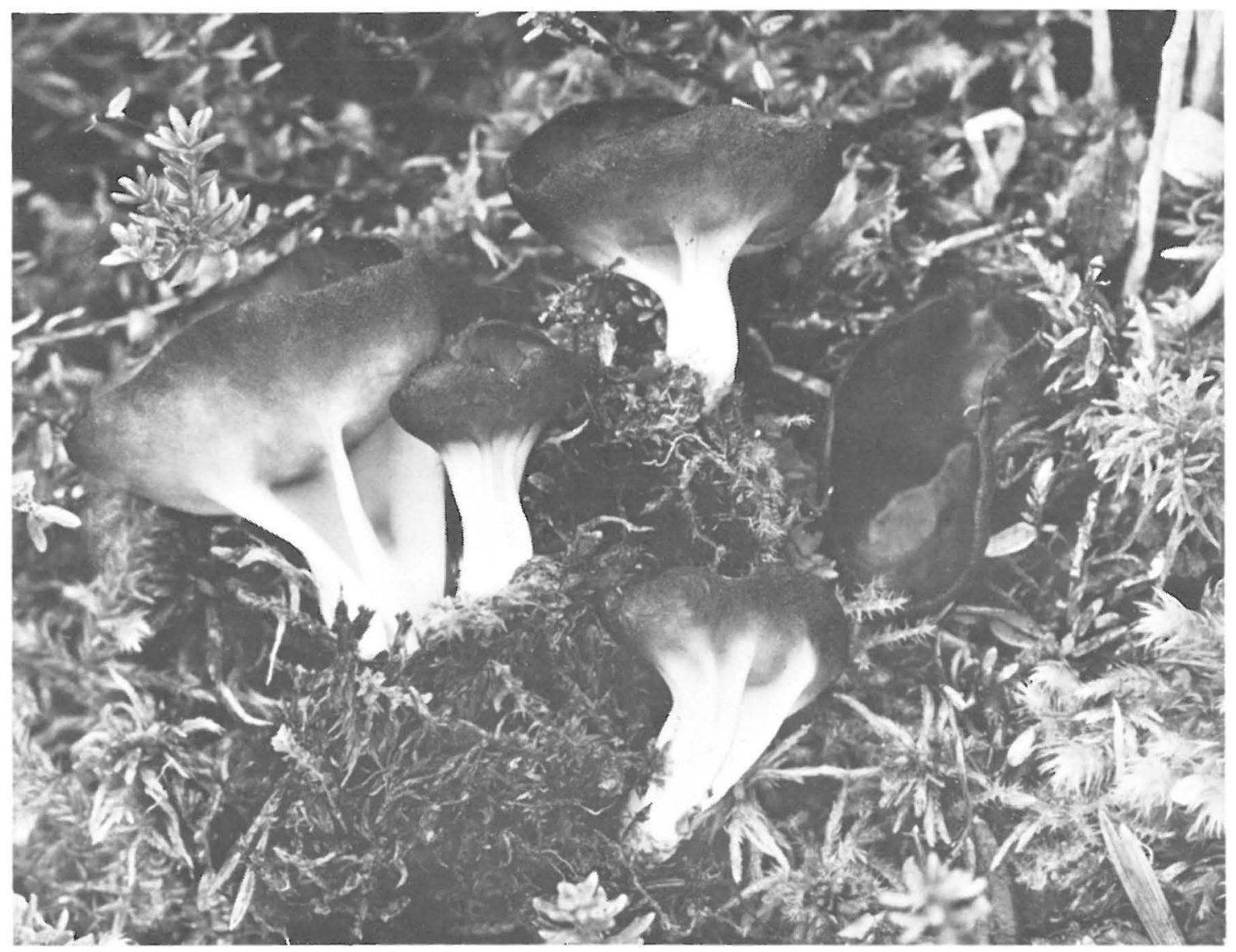

Fig. 1. Helvella hyperborea fresh in situ, slightly magnified (Finland, Kuusamo, Liikasenvaara, 23.VIII.1978 Harmaja; H). - Photo: Mauri Korhonen.

The most important characters separating $H$. hyperborea from the very closely related $H$. costifera s.str. are presented in Table 1. These rather variable species should be identified on the basis of the combination of all their characters, since there is no single conspicuous feature differentiating them alone and in all cases. In general, young apothecia of the two species may be very alike, especially macroscopically, but with age those of $H$. hyperborea assume the features peculiar to that species while the fruit bodies of $H$. costifera change to a lesser degree as they develop.

Some minor or less obvious differences between the species are mentioned in the following. In $H$. hyperborea the diameter of the apothecium tends to be slightly smaller, the stipe is often slightly longer and more slender and generally widens more abruptly to the cup. The hyphae forming the textura intricata of the ental excipulum are more strongly inflated in places in $H$. hyperborea. The walls of these hyphae have usually a faint brownish tinge in $H$. hyperborea, while in $H$. costifera they are usually hyaline or practically hyaline (more rarely pale brownish). The cell walls in the apothecium are thinner throughout in $H$. hyperborea: the walls of the hyphae of the ental excipulum, those of the cells of the textura prismatica, and those of the asci. There may also be a slight difference in the substrate from which the apothecia emerge: $H$. hyperborea often grows in a mixture of bare soil, mainly mull, and different kinds of plant litter (occasionally apparently even in litter alone), while $H$. costifera almost always occurs on bare, often more or less clayey, soil.

Characters shared by $H$. costifera and $H$. hyperborea are the usually grey-brown colour (often with fulvous shades or spots when dry) of the cup 
Table 1. The most important characters differentiating Helvella costifera and $H$. hyperborea. The microscopic characters were observed in sections made of the dry apothecium c. 1-3 mm below the cup margin and mounted in Melzer's reagent.

\section{Character \\ Colour of hymenium}

Ribs of cup exterior, especially as observed in dried condition

Surface of cup exterior near
margin

Consistency of dried apothecium

Shape of mature spores (besides a few slightly ovoid spores)

Paraphysis apices: diameter and shape

Pigmentation of paraphyses

Diameter of hyphae in ental excipulum (textura intricata)

Colour of the usually thin encrustation of cell wall in ectal excipulum, esp. in its outer part (t. prismatica)

Human influence in habitat in Fennoscandia and Denmark

Fruiting period in Fennoscandia and Denmark (Fig. 4)

Zonal distribution in Fennoscandia and Denmark (Fig. 5)

\section{Illustrations}

\section{H. costifera}

pure light grey to pale brown-grey when fresh, fairly pale to medium brown (at times darker, rarely even black-brown) when dry

(with occasional exceptions) very conspicuous and prominent, abundant, extending slightly more to much more than halfway up cup, repeatedly branching, \pm anastomosed

with fine but almost always \pm distinct hyaline to pale brown pubescence or villosity

hard, horny

most truly ellipsoid, a minority oblong-ellipsoid

3.0-6.0(-7.0) $\mu \mathrm{m}$, slightly expanded (gradually)

wall encrustation mostly absent or hyaline and hence inconspicuous, pale brown encrustation very occasionally present in places; contents pale brown to practically hyaline; hymenium colour almost always of about uniform intensity throughout

$2.0-8.0(-12.0) \mu \mathrm{m}$

usually almost hyaline, at times pale brown, exceptionally medium brown in a few places (e.g. at some septa)

probably always distinct; mostly found in man-made sites such as parks, gardens and roadsides

late June to beginning of October, mostly in July and August

temperate to middle (oro)boreal, with a preference for southern and low-lying areas

Dähncke \& Dähncke 1979: 655, as Paxina sulcata (fresh). This paper: Fig. 3 (dry)

\section{H. hyperborea}

mostly dark grey-brown when fresh and dark brown to black when dry; rarely paler: browngrey to grey-brown when fresh and medium brown when dry

less conspicuous and prominent, usually fewer, extending about halfway up cup, mostly simple or shortly forked distally, only very rarely with a few indistinct anastomoses

with \pm delicate brown (mostly dark) pubescence, usually appearing glabrous to bare eye

'normal', i.e. not hard (excepting some young or much pressed or otherwise improperly treated apothecia)

most almost always oblongellipsoid, a minority truly ellipsoid

4.0-7.5(-9.0) $\mu \mathrm{m}$, somewhat expanded (less gradually)

medium (rarely pale) brown wall encrustation present above; contents \pm pale brown above; hymenium darker above

$2.5-11.0(-15.0) \mu \mathrm{m}$

pale to dark brown, colour intensity sometimes varying within small area, encrustation often thickest and darkest in outermost cell chains and end cells

mostly lacking, sometimes present

late July to mid-September

middle boreal to lower oroarctic (low alpine), optimal area apparently northern boreal zone

This paper: Figs. 1 (fresh) and 2 (dry) 
Table 2. The most important characters differentiating Helvella leucomelaena, $H$. confusa, $H$. pedunculata and $H$. oblongispora. The microscopic characters were observed in sections made of the dry apothecium ca. $1-3 \mathrm{~mm}$ below the cup margin and mounted in Melzer's reagent (and $5 \% \mathrm{KOH}$ ). The size and shape of the spores refer to mature, hyaline, ones.

Character

Apothecium

diameter

Stipe

Cup shape in age

Ribs on cup exterior

Surface of cup exterior near margin

Colour of dry external surface

Colour of dry hymenium

$\begin{array}{ll}\text { Spore size } & 19.0-24.0 \times \\ & 10.5-13.0 \mu \mathrm{m}\end{array}$

Spore shape
H. leucomelaena

$$
1.5-7 \mathrm{~cm}
$$

mostly indistinct, short, almost always fairly thick, with \pm obtuse single ribs, usually widening to cup \pm gradually

remaining concave, \pm cupulate

none, or a few obtuse folds lowest down

very finely pubescent, appearing glabrous or almost glabrous to bare eye

white (rarely yellowish) below, greyish to dark brown near cup margin

dark brown to black-brown

$$
\begin{aligned}
& 19.0-24.0 \times \\
& 10.5-13.0 \mu \mathrm{m}
\end{aligned}
$$

ellipsoid to oblong
H. confusa

$1-3 \mathrm{~cm}$

well differentiated, rather short, rather slender, with obtuse almost always single ribs, meeting the cup \pm abruptly

remaining concave, \pm cupulate

none, or a few obtuse ones lowest down

very finely pubescent, appearing glabrous or almost glabrous to bare eye

white (rarely yellowish) below, greyish to dark brown near cup margin

mostly dark brown, rarely black-brown

$18.0-22.5 \times$

$11.5-14.5 \mu \mathrm{m}$

most ellipsoid, some \pm oblong
H. pedunculata

$1-3(-4) \mathrm{cm}$

very well differen-

tiated, rather

short, almost al-

ways slender, very

often compressed,

with \pm obtuse

almost always single ribs, meeting the cup very abruptly (the ribs may be practically absent from

young or otherwise small apothecia)

becoming distinctly shallower, finally usually (always?) plane (or even somewhat convex) with undulating margin

mostly none, at times a few obtuse folds lowest down

generally slightly more coarsely pubescent

white (at times yellowish) below, greyish to dark brown near cup margin

dark brown to black

17.5-20.0 $(-22.5) \times 10.5-$ $12.5(-13.5) \mu \mathrm{m}$

most ellipsoid, a few somewhat ovoid and oblong
$H$. oblongispora

$1.5-5 \mathrm{~cm}$

\pm distinct, rather short to short, fairly thick, with very distinct obtuse to rather angular ribs, some of which tend to be double-edged, widening to cup \pm gradually

becoming somewhat shallower but remaining concave and \pm cupulate

present on the lowest fourth to third, \pm distinct, obtuse

extremely finely pubescent, appearing to bare eye as if covered by thin pale grey pruina (fairly distinct esp. where ground colour fairly dark)

mostly yellowish to yellow, but pale to medium brown in places near cup margin

rather pale to medium brown

$17.5-21.0 \times$ $10.5-13.0 \mu \mathrm{m}$

most pronouncedly oblong, remainder ellipsoid 
exterior, at least near the margin, the white to buff (esp. when dry) colour of the basal parts of the apothecium, and ribs of the fruit body with blunt edges, which are sometimes double and at times \pm sharp below. The cup may have a 'white margin' (cf. Harmaja 1977b: 50) in both species, but rather seldom. The mature spores measure 14.5-18.0 $\times$ $9.5-11.5 \mu \mathrm{m}$ in both. A fairly good proportion of the submature spores are subfusiform, a few being truly fusiform. The terminal cells of the paraphyses are about $50-150 \mu \mathrm{m}$ long in both (but tend to be slightly shorter in $H$. hyperborea?). The ectal excipulum is composed of somewhat elongated rather small cells, roughly $10-30 \mu \mathrm{m}$ long, and is fairly homogeneous in structure, i.e. it is sometimes not easy to distinguish an inner layer of $t$. angularis and an outer one of $t$. prismatica. In thin and well-stained sections of mature apothecia the contents of the paraphyses and $t$. prismatica cells are weakly to moderately cyanophilic, strongly cyanophilic septal collars are common and fairly conspicuous in the whole excipulum, but cyanophilic intercellular matter is lacking or scanty in the t. angularis. Apart from the more abundant pigmentation of $H$. hyperborea, $\mathrm{KOH}(5 \%)$ sections of the two species are very alike as to colour: no colour reactions are provoked. The end cells in the tufts of the extal excipulum are \pm clavate and rather small, measuring about $6-30 \times$ $5-13 \mu \mathrm{m}$ in both (they may be generally slightly thicker and shorter in $H$. hyperborea). The ascus development was found to be pleurorhynchous in both species, the type specimens also being studied. Both species seem to require \pm calcareous ground. The habitat is mostly well-drained, but some sites of $H$. hyperborea consist of more or less paludified spring-fed places or wet brooksides. H. hyperborea
Table 2 (contd.).

Character

Ental excipulum: diameter of the t. intricata hyphae

Shape of $t$. intricata hyphae

Ectal excipulum (invariably scantily pigmented innermost part excluded): colour in Melzer's and $\mathrm{KOH}$

Ectal excipulum: appearance of $t$. angularis layer

Ectal excipulum: width of \pm elongated cells of $t$. angularis

Illustrations

\begin{abstract}
H. leucomelaena
$2.0-10.0 \mu \mathrm{m}$

frequently and distinctly constricted at septa and inflated between them

pale to medium brown due to intracellular and indistinct thin encrusted pigments, somewhat to distinctly darker than ental one
\end{abstract}

rather irregular

$5-25 \mu \mathrm{m}$

Dissing 1966: Fig. 8 (fresh)

\author{
H. confusa \\ $2.0-4.5(-7.0)$ \\ $\mu \mathrm{m}$ \\ fairly uniform in \\ diameter \\ medium to fairly \\ pale brown due to \\ intracellular and \\ locally fairly dis- \\ tinct encrusted \\ pigments, \pm dis- \\ tinctly darker than \\ ental one
}

rather irregular

$5-22 \mu \mathrm{m}$

Dissing 1966: Fig. 10 , as $H$. solitaria (fresh.) ?Dähncke \& Dähncke 1979: 653, as Paxina acetabulum (fresh) rather irregular

$5-25 \mu \mathrm{m}$

H. pedunculata

$2.5-12.5(-17.0)$

$\mu \mathrm{m}$

frequently \pm constricted at septa and \pm inflated between them

medium brown due to intracellular and frequent distinct encrusted, even dark brown, pigments, distinctly darker than ental one

This paper: Fig. 6 (dry)
H. oblongispora

$2.0-4.0(-6.0)$

$\mu \mathrm{m}$

fairly uniform in diameter

very pale throughout: in Melzer's pale honey-colour, in $\mathrm{KOH}$ hyaline or almost hyaline, because of lack of distinct pigments, concolorous with ental excipulum (locally slightly darker)

fairly regular

$5-17(-22) \mu \mathrm{m}$

This paper: Fig. 7 (dry) 

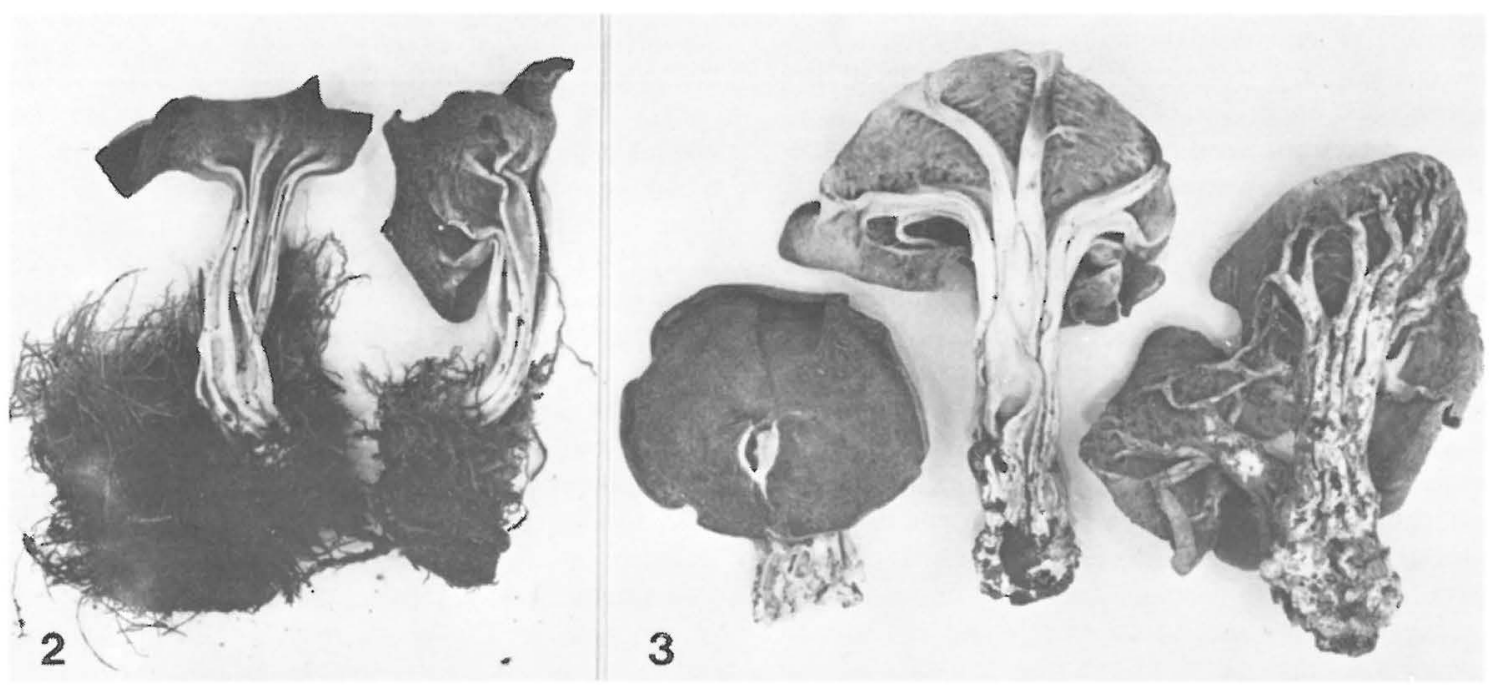

Figs. 2-3. Dried apothecia, $\times 1.5 .-2$ : Helvella hyperborea (type). $-3: H$. costifera (two apothecia on the left: Norway, Akershus, Oslo, Bakkehaugen, VII.1948 Bratsberg, O; one apothecium on the right: Sweden, Uppland, Uppsala, Botanical garden, 22.VI.1948 Smith, UPS). - Photo: Mauri Korhonen.

has been found in the company of, for example, Dryas octopetala, Rhododendron lapponicum, Salix glauca, S. hastata, and Viola biflora (label notes); several accompanying plant and fungus species are listed in three previous papers dealing with the fungi of Kuusamo (Harmaja 1974:116, 1976a:21, 1976b:27-28, 1977c), and to these may now be added Lactuca alpina, Helvella palustris, $H$. sp. aff. pezizoides (H. pezizoides in Harmaja 1976b:28), and Peziza gerardii.

H. costifera is distributed in Fennoscandia and Denmark from the temperate zone to the lower part of the middle (oro)boreal zone and is known from near sea level up to ca. $500 \mathrm{~m}$ (Oppland, S. Norway). $H$. hyperborea occurs from the middle boreal zone to the lower oroarctic (low alpine) zone and from near sea level up to ca. $1400 \mathrm{~m}$ (Buskerud, S. Norway). The species thus appear to be partially sympatric.

\section{June July August September}

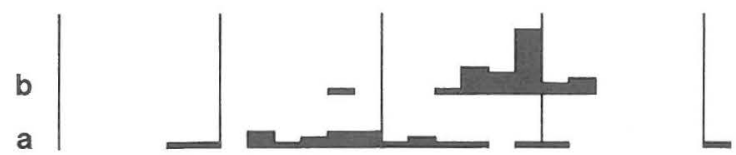

Fig. 4. Phenological diagram showing the fruiting periods of Helvella costifera (a) and $H$. hyperborea (b) in Fennoscandia and Denmark. For construction of the diagram, see the legend of Fig. 14 in Harmaja 1977b.
Outside Fennoscandia, $H$. costifera has also been collected in the upper oroboreal zone (Yukon, coll. Ahti 23071).

$H$. costifera and $H$. hyperborea belong to Helvella St-Am. sect. Acetabulum Diss. They differ from $H$. acetabulum and $H$. arctoalpina Harmaja mainly in the blunt ribs of the cup, the usual absence of orangetinged to yellow-tinged brown or true yellow from the colour of their dry apothecia, and the somewhat different, more uniform, aspect of the ectal excipulum (cf. Harmaja 1977b). The fruiting periods of the two species are much to somewhat later than that of $H$. acetabulum, and the amount of cyanophilic intercellular matter in the $t$. angularis is smaller. $H$. hyperborea also differs from $H$. acetabulum in the brown encrustation of the cell walls in the outer part of the ectal excipulum. In addition, $H$. hyperborea is separated from the arcticalpine species $H$. arctoalpina and $H$. dryadophila Harmaja, which are partially sympatric with it, by the smaller spores, the ectal excipulum, which has smaller cells (including the terminal ones), and less conspicuous pigmentation and the longer end cells of the paraphyses (cf. Harmaja 1977b).

\section{Specimens examined:}

\section{Helvella costifera}

Sweden. Uppland. Stockholm: Bergius Garden, 1974 Kers 4116 (S). Uppsala: 15 specimens (S, UPS), mainly from parks and gardens, 1851-1971, incl. 1851 E.P. Fries 


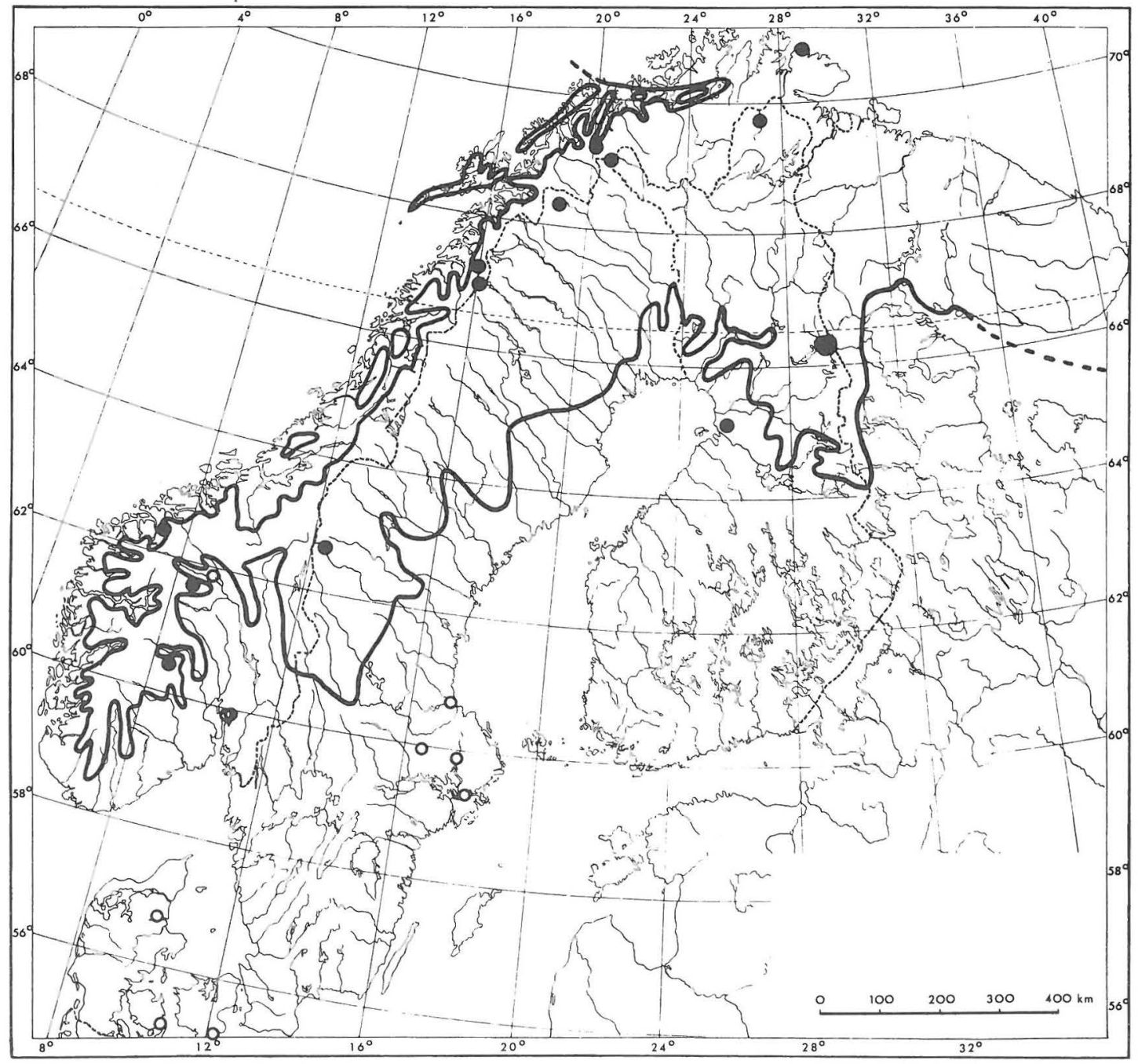

Fig. 5. Map of distributions of Helvella costifera (circles) and H. hyperborea (dots) in Fennoscandia and Denmark, based on all the specimens actually seen by the author. The thick line is the border between the middle boreal and northern boreal zones according to Ahti et al. (1968).

(lectotype?, UPS; isolectotype?, S) and Lundell \& Nannfeldt: Fungi Exs. Suec. 2061 (S, UPS). Västmanland. Sala: on paths under Corylus avellana, 1948 Morander 1350 (UPS). - Gästrikland. Gävle: Stadsparken, 1902 Starbäck (S).

Norway. Akershus. Bærum: Høvik, 1964 Kvavik (O). Oslo: Vestre Aker, Bakkehaugen, 1948 Bratsberg (O) (Dissing 1966, as $H$. acetabulum), 1950 Bratsberg (O); Bygdøy, 1956 Eckblad (2 exx., O). - Oppland. Vågå: Vảgåmo, under Betula, 1957 Eckblad (0), above Jutulporten, 500 m, 1973 Løkken $(\mathrm{O})$.

Denmark. Jylland. Ålborg Amt: Kielstrup Sø, under Fagus sylvatica, 1966 Toft (C). - Fyn. Svendborg Amt: Elsehoved, Lundeborgskoven, 1962 Hansen (C). Sjcelland. Præstø Amt: Møns Klinteskov, 1954 Lange \& Heim (C).
Netherlands. Limburg. Valkenburg: 1899 Rick (S).

Switzerland. Kt. Graubünden. Arosa: stony soil, 1963 Rahm (C).

Czechoslovakia. Morava. Lednice [Eisgrub]: in park under Tilia, 1912 Zimmermann (S), Petrak: Fl. Bohem. Morav. Exs. 251 (2 exx., S). Jeseník [Freiwaldsau]: 1905 Buchs (S). Hungary. Pest. Kecskemét: 1897 Hollós (S).

Italy. Trentino-Alto Adige. Andalo: coniferous forest, 1901 Bresadola (S). Gocciadoro: 1896 Bresadola (S). Sopramonte: 1893 Turco-Lazzato (S). Terzolaj: coniferous forest, 1883 Bresadola (S). - Toscana. Firenze: 1898 Mattirolo (S).

U.S.A. Wisconsin. Algoma: 1909 Dodge (S).

Canada. Yukon. Kluane Lake: Sheep Mountain, $1000 \mathrm{~m}$, arid calcareous Picea glauca forest, near common camping place, 1967 Ahti $23071(\mathrm{H})$. 


\section{Helvella hyperborea}

Finland. Pohjois-Pohjanmaa. Kiiminki: Raivio, limestone area, 1966 Korva \& Ulvinen (OULU); Keskikylä, 1979 Ulvinen (OULU). - Kuusamo. Kuusamo: Oulanka Nat. Park, 170-235 m, 1970-1974, Harmaja, Ulvinen (4 exx., $\mathrm{H}$, OULU); Liikasenvaara, 1970 Ulvinen (OULU), $270 \mathrm{~m}$, 1978 Harmaja (H, C); Juuma, 205-210 m, 1970-1978, Harmaja, Harmaja et al., Tuomikoski, Ulvinen (6 exx., H, OULU). - Enontekiön Lappi. Enontekiö: Kilpisjärvi, 510-700 m, 1979 Harmaja (5 exx., H). - Inarin Lappi. Utsjoki: Kevo, 1964 Kallio (TUR) (Kallio \& Kankainen 1964 , as $H$. acetabulum).

Sweden. Härjedalen. Tännäs: Ramundberget, schistose rock, 1947 Rydberg (S). - Torne Lappmark. Kiruna (Jukkasjärvi): Abisko, alpine heath, 1950 Holm (UPS).

Norway. Oppland. Lom: Soleggen, schist gravel, 1957 Eckblad (O). - Buskerud. Hol: Ustaoset, Djuptjønnhovda, $1373 \mathrm{~m}$, heath, 1960 Sivertsen (O) (Dissing 1966, as H. acetabulum). - Møre og Romsdal. Stordal: Korsedal, Simotjønnet, 1966 Nordhagen (O). Nordland. Fauske: Blåmannsisen W, Gamhaugen N, 375-400 m, 1967 Sivertsen (TROM) [a typical and representative specimen]. Saltdal: NW side of Nord-Saulo, 800 m, 1966 Sivertsen (TROM). - Troms. Storfjord: 1965 Lange (C). - Finnmark. Berlevåg: 1864 Th.M. Fries (UPS).

Iceland. Hveragerði: Selfjall, 1959 Lange 20 (C); Tindar, 1959 Lange 659 (C) (Dissing 1966, as H. acetabulum).

\section{Helvella pedunculata and $\mathbf{H}$. oblongispora}

As shown by Harmaja (1977a), the prevailing concept of H. solitaria Karst. (Dissing 1966) is based on three different species at least: $H$. solitaria as defined by the type specimen (syn. $H$. queletii Bres.), $H$. leucomelaena (Pers.) Nannf., and $H$. confusa Harmaja n.sp. Later, additional material published as $H$. solitaria by Dissing (1966) turned out to represent a fourth species, $H$. pedunculata Harmaja (Harmaja 1978). Further specimens from Norway and Finland, not considered by Dissing (1966, mostly having been collected too recently), also belong to $H$. pedunculata. This and another newly described species, H. oblongispora Harmaja (Harmaja 1978), will be treated more fully in the present chapter. Like $H$. confusa and $H$. pedunculata, but unlike the true $H$. solitaria, $H$. oblongispora should be included in sect. Leucomelaenae Diss., chiefly because of the kind of its ascus development. The four known specimens of $H$. oblongispora were earlier identified as $H$. costifera or $H$. leucomelaena. In this connection the characters of $H$. confusa and its delimitation from $H$. leucomelaena will be presented in more detail than before (Harmaja 1977a).

Table 2 shows the most important characters differentiating $H$. leucomelaena, $H$. confusa, $H$. pedunculata and $H$. oblongispora, and also contains references to illustrations.
Some less conspicuous or indistinct specific differences were also observed in the group. The $t$. prismatica layer of $\mathrm{H}$. oblongispora consists almost entirely of end cells, and its cell tufts are very weakly developed, as is evident to the naked eye from the nature of the sterile surface of the cup (see Table 2). Throughout the ectal excipulum the cell walls are thinnest in $H$. oblongispora, and in the $t$. prismatica the cell walls appear thickest in $H$. pedunculata. The present material does not allow definite conclusions about differences in distribution, but $H$. confusa may be absent from the boreal zones, while $H$. pedunculata has been found from the hemiboreal to the northern boreal zone (as defined by Ahti et al. 1968).

$H$. leucomelaena, $H$. confusa, $H$. pedunculata and $H$. oblongispora are very closely related to each other, especially the first three; the distance between them and $H$. oblongispora is somewhat greater. The following important characters are common to all four. The submature spores are somewhat larger than the ripe ones, and occasionally subfusiform. The paraphyses are very similar: they are filiform to clavate, a few being subcapitate, their apical diameter is $4-8(-10) \mu \mathrm{m}$, they have thin walls, which lack any conspicuous encrustation, their contents are more or less pale brownish and homogeneous, and their end cells are of about the same length, or ca. (50-)75-150 $\mu \mathrm{m}$ (possibly slightly shorter in $H$. oblongispora). The ental excipulum consists of $t$. intricata with thin hyaline hyphal walls. The structure of the ectal excipulum is fairly similar in the four species (but see Table 2 and preceding section) and is composed of an inner layer of $t$. angularis with more or less elongated cells (with their longer axis perpendicular to the apothecium surface), and an outer part of more or less developed $t$. prismatica. The end cells of the tufts of the latter part are clavate and fairly large, measuring about $15-50 \times 7-15$ $\mu \mathrm{m}$. The asci are very alike in all four species: eightspored, with about the same wall thickness, with dextrinoid contents when young, and an aporhynchous base. Microscopic sections in $\mathrm{KOH}(5$ $\%$ ) or heated cotton blue did not display further specific differences. Intercellular cyanophilic matter, other than in the form of scattered septal collars, is absent from the excipuli. So far no differences are known in the phenology or habitats of the four species; they all grow on more or less bare distinctly calcareous soil.

A 'white margin' (see Harmaja 1977b:50) has been observed in the cups of some collections of $H$. pedunculata. 
6
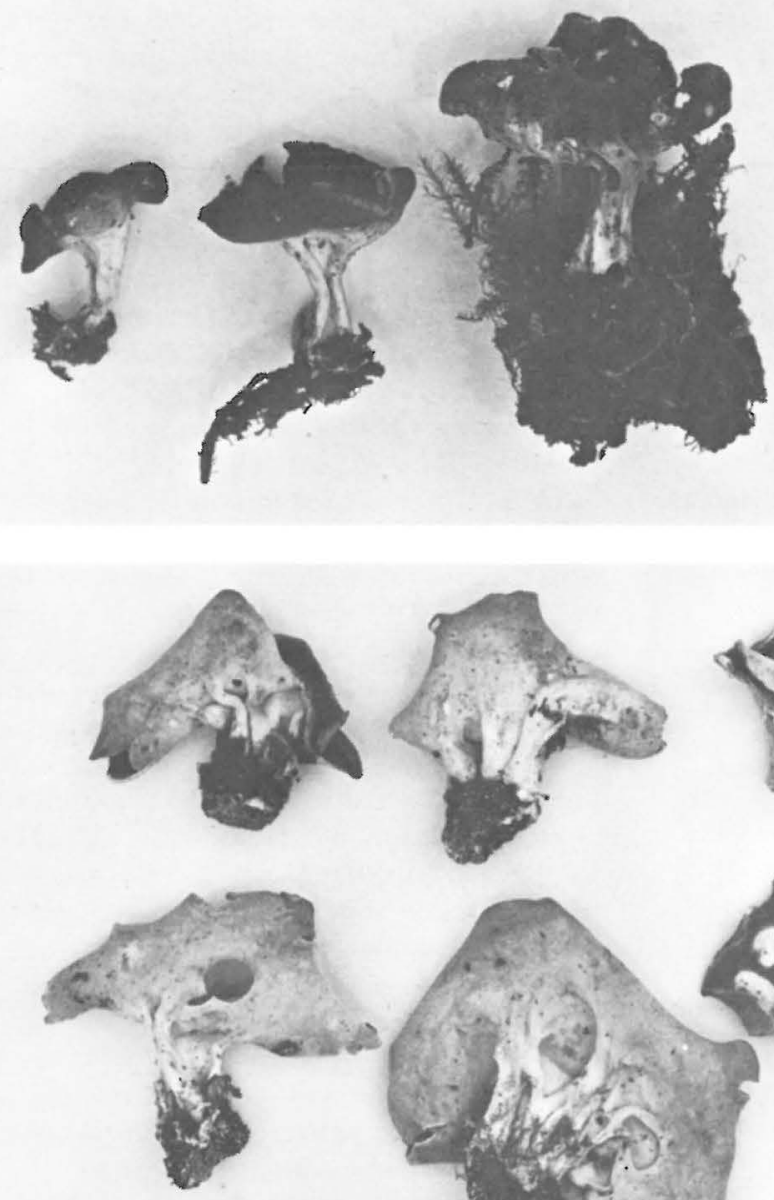

7
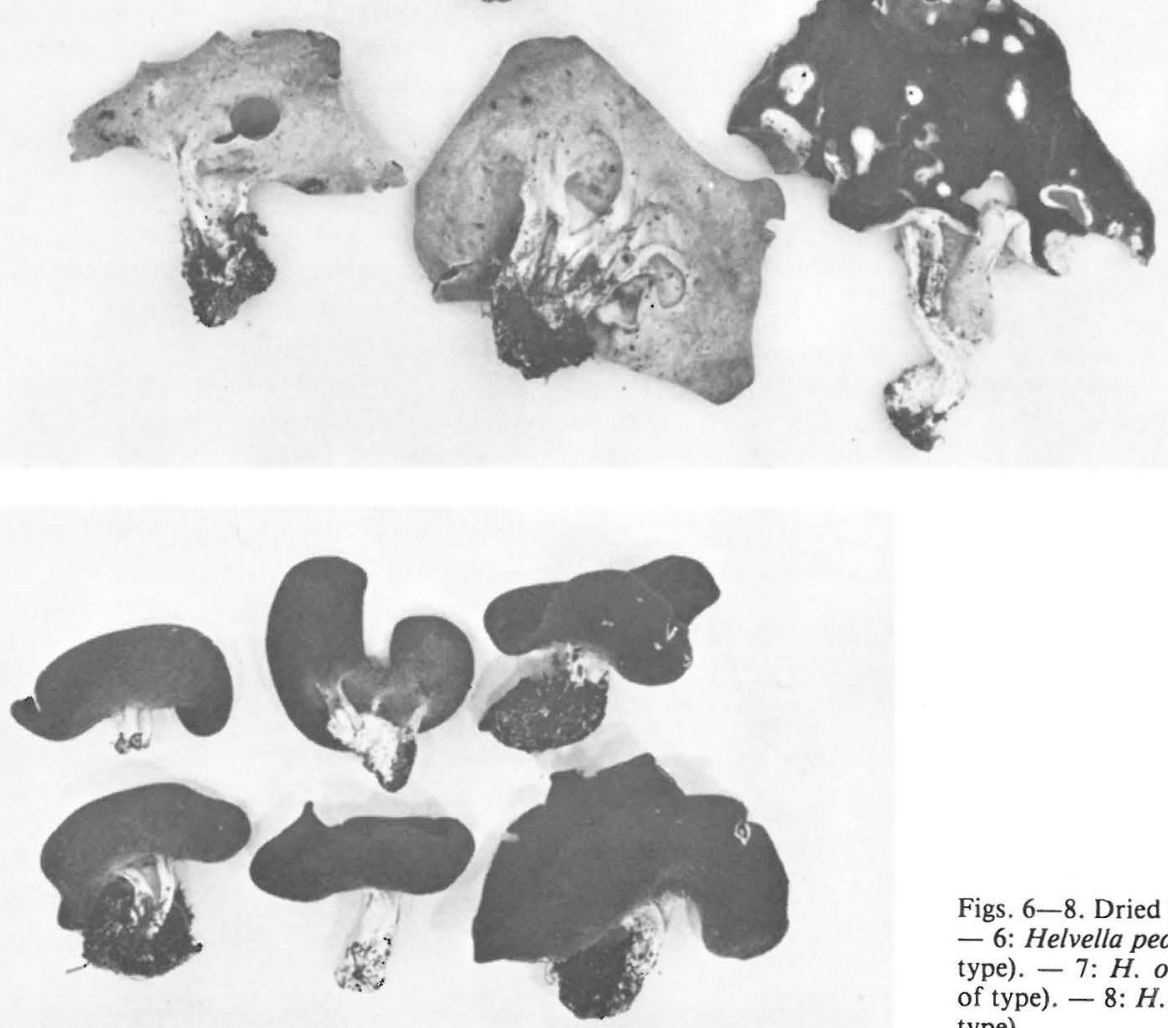

8

Figs. 6-8. Dried apothecia, $\times 1.5$. - 6: Helvella pedunculata (part of type). - 7: $\mathrm{H}$. oblongispora (part of type). $-8: H$. ulvinenii (part of type).

- Photo: Mauri Korhonen. 
Dissing (1966) reported having detected ' $H$. solitaria' in five different exsiccates, in the copies of various herbaria (but not $\mathrm{H}$, whose collections he scarcely studied at all). $\mathrm{H}$ contains specimens with the corresponding numbers belonging to two of these exsiccates. One of the specimens (Rehm: 'Ascomyceten', no. 751), and one specimen from each of two exsiccates not mentioned by Dissing but deposited in $\mathrm{H}$, have been determined as $H$. confusa (Harmaja 1977a). The other exsiccate examined by Dissing and filed in H is Saccardo's 'Mycotheca Italica'. I wish to report here that specimen no. 663 of this exsiccate in H ('Acetabula calyx Sacc.') represents the true $H$. solitaria. However, it should be kept in mind that the copies of exsiccates in different herbaria may comprise heterogeneous material.

\section{Specimens examined}

\section{Helvella pedunculata}

Finland. Ahvenanmaa. Saltvik: Ödkarby, Hjortö, VI.1949 Schulmann (H) (Schulmann 1955, as Macropodia bulbosa). - Kainuu. Puolanka: Väyrylä, Vuorijärvi, schistose rock, 30.VI.1973 M. Ohenoja (OULU). - Pohjois-Pohjanmaa. Kiiminki: Isohalmeenmaa, calcareous boulder, 10.VIII.1971 Ulvinen (OULU), mineral soil, 4.IX.1971 M. Ohenoja (OULU); Keskikylä, old trail, 2.VII.1975 E. Ohenoja (OULU), among moss in rich fen, 2.VII.1975 E. \& M. Ohenoja (type; OULU); limestone area, SW of Raivio, 19.VII.1975 Ulvinen (OULU). - Kuusamo. Kuusamo: Oulanka Nat. Park, Biol. Sta., 25.VII.1967 Ulvinen (OULU), Kiutaköngäs, 10.VIII.1975 E. Ohenoja (OULU), Ampumavaara, 11.VII.1968 Jakkula (OULU), $180 \mathrm{~m}$, 24. VIII.1979 Ulvinen (OULU).

Norway. Østfold. Onsøy: Engalsvik, 8.VII.1956 \& 22.VI.1971 Eftestøl (O) (Dissing 1966, as H. solitaria); near Grundvig, 17.VI.1967 Eftestøl (O), 21.VI.1967 Eftestøl (O). - Hedmark. Åmot: Åsbygda by Rena, $370 \mathrm{~m}$, ?15.VII.1957 Berg (O) (Dissing 1966, as H. solitaria). Nordland. Rana: Dunderlandsdalen, Ørtfjellmoen, 11.IX.1976 Jakowlev \& Ulvinen (OULU).

\section{Helvella oblongispora}

Sweden. Västmanland. Sala: Gröna gången, near MånsOls, among stones on canal embankment, 2.VII.1945 Morander 60 (UPS) (Dissing 1966, as H. costifera; Harmaja $1977 \mathrm{~b}$, as $H$. acetabulum).

Norway. Oppland. Østre Gausdal: near fjeld Bjørga, 800-900 m, among moss near a spring, 10.IX.1952 Størmer (O) (Dissing 1966, as H. leucomelaena).

Germany (BRD). Bayern. München area: abundant on calcareous soil under conifers near the Isar, 23.VII.1969 Einhellinger (type; C).

Austria. Tyrol. Stubaier Alpen: by road to Obernberger-See near Tribulaun, 1900 m, IX.1907 Rehm (S) (Dissing 1966, as $H$. costifera).

\section{Helvella ulvinenii Harmaja n.sp.}

Helvella ulvinenii Harmaja n.sp. - A Helvella solitaria praecipue differt superficie exteriori cupulae atrobrunneo, sporis minoribus (14.5-17.0 $\times$ 10.0-11.5 $\mu \mathrm{m}$ ) semper ellipsoideis non nec excipulo dissimili. - Typus: Finland, prov. Enontekiön Lappi, par. Enontekiö, Kilpisjärvi, NE slope of W peak of fjeld Pikku-Malla, alt. ca. $650 \mathrm{~m}, 18$ apothecia in orohemiarctic eutrophic dry heath below a low dolomitic rock, with Betula nana, Juniperus communis, Salix arbuscula, S. glauca, S. herbacea, $S$. lanata, S. reticulata, Dryas octopetala, Hylocomium splendens, Cetraria nivalis, Peltigera leucophlebia, Amanita cf. hyperborea, Clitocybe strigosa, Lactarius dryadophilus, 25.VIII.1979 Harri Harmaja ( $\mathrm{H}$, holotype; OULU, isotype).

Apothecia $1-3 \mathrm{~cm}$ high and $1.5-4 \mathrm{~cm}$ in diameter, differentiated into distinct cup and stipe.

Cup \pm compressed laterally, the 'lobes' thus formed being recurved; ribs of stipe do not continue on to cup, or do so very shortly. Hymenium dark sepia brown when fresh, black when dry. External surface when fresh concolorous with hymenium, except for the base, which is medium to pale greybrown with small white areas next to stipe; throughout covered with small warts, which become larger towards margin and are fairly pale grey-brown (i.e. paler than ground colour). When dry, external surface black-brown, excepting the base which is grey with some small pale orange patches; warts inconspicuous, generally slightly paler than ground colour.

Stipe $0.5-1.5 \mathrm{~cm}$ high and $0.3-0.6(-1.5) \mathrm{cm}$ wide, often compressed, white when fresh, white or with pale grey or pale orange tinges in places when dry; throughout with conspicuous single or indistinctly double blunt-edged ribs.

Spores $14.5-17.0 \times 10.0-11.5 \mu \mathrm{m}$, fairly broadly to moderately ellipsoid, with one large ellipsoid oil drop; of about the same size and shape when submature.

Asci large, tapering apically, pleurorhynchous, eight-spored, thick-walled.

Paraphyses with clavate, at times subcapitate, apex, which is $5.0-10.0 \mu \mathrm{m}$ in diameter; wall thin, with some \pm inconspicuous hyaline to pale brown encrustation above; contents pale to medium brown, almost homogeneous to somewhat granular; end cell very long, ca. $70-180 \mu \mathrm{m}$ (mostly longer than 100 $\mu \mathrm{m})$.

Anatomy. Excipulum composed of 3 layers. Ental part of $t$. intricata with narrow $(2.5-6.0(-7.0) \mu \mathrm{m}$ in diameter) hyphae, which widen in places, gradually to abruptly, to often conspicuous elongate to globose cells, $7-30 \mu \mathrm{m}$ in diameter; walls thin to somewhat thickened, almost all hyaline. Middle layer ca. 
$110-140 \mu \mathrm{m}$ thick, of untypical $t$. angularis with tendencies towards $t$. globulosa and t. prismatica; cell walls \pm widely covered with dark brown encrustation, especially in septal regions. Outermost layer consists of \pm separate fairly small tufts of $\pm t$. prismatica; cell walls ca. $0.5-1.0(-1.5) \mu \mathrm{m}$ thick, with dark brown encrustation in places; cell contents pale to dark brown; end cells $12-30 \times 7-16 \mu \mathrm{m}, \pm$ clavate, collapsed and throughout hyaline in places.

The microscopic characters described above have been examined on Melzer mounts.

The features of $H$. ulvinenii did not fit with $H$. queletii var. alpina Heim \& Remy or any other taxon described in the literature. The species has the same shape and macroscopic structure of the apothecium as the no doubt closely related $H$. solitaria Karst. ( $H$. queletii Bres.; cf. Harmaja 1977a), but differs from it in the following respects: (1) in $H$. Ulvinenii the outside of the cup is darker and without a distinct grey tinge, (2) the mature spores are shorter $(16.0-19.0(-20.0) \times 10.0-11.5 \mu \mathrm{m}$ in $H$. solitaria), (3) the mature spores are relatively broader (fairly narrowly to moderately ellipsoid with fairly many subfusiform ones in $H$. solitaria), (4) the submature spores do not differ in size or shape from the mature ones (most submature spores larger than the mature ones, even up to $24 \times 15 \mu \mathrm{m}$, and a good many of them subfusiform or fusiform in $H$. solitaria; Harmaja 1977a), (5) the hyphae of the ental excipulum are slightly wider and in places are inflated to often conspicuous elongate to globose cells (most hyphae $2.0-4.5(-6.0) \mu \mathrm{m}$ in diameter and only a very few of them distinctly inflated, mainly in the uppermost parts of the ental excipulum, in $H$. solitaria), (6) the cells in the $t$. angularis layer are somewhat larger, (7) the cell walls in the $t$. prismatica tufts are slightly thicker (ca. $0.4-0.8 \mu$ m thick in $H$. solitaria), (8) the last-named cell walls have distinctly darker encrustation, and (9) the end cells in the chains of the $t$. prismatica tufts are larger $(5.0-13.0 \mu \mathrm{m}$ wide in $H$. solitaria). In addition, $H$. ulvinenii may possibly be differentiated by the following features: the colour of the fresh hymenium is pure brown without a greyish tinge; the warts on the outside of the cup are generally smaller; the stipe tends to be smaller; the apices of the paraphyses are generally wider; the distribution may be more restricted $(H$. solitaria occurs both at low altitudes and above the forest limit: Harmaja (1977a and b); an oroarctic specimen has also been collected in Finnish Lapland in the Kilpisjärvi region: fjeld Saana, 13.IX.1967 Ulvinen, OULU). $H$. ulvinenii may also be fairly close to $H$. dryadophila Harmaja, but is easily separated from this species and from all the other similar-looking species of arctic-alpine habitats by the characteristic shape of the apothecium, the short spores (but also short in $H$. hyperborea Harmaja), the very long end cells of the paraphyses (also long in $H$. hyperborea), and some less conspicuous details.

I have great pleasure in naming the new species in honour of Mr. Tauno Ulvinen, Lic.Phil., Curator of the Herbarium of the University of Oulu, a very active and notable person in different branches of Finnish mycology.

\section{New records of $H$. dryadophila from Finland and Norway}

Finland. Enontekiön Lappi. Enontekiö: Kilpisjärvi, E slope of fjeld Pikku-Malla, 570-580 m, orohemiarctic mesic to fresh eutrophic heath, on bare soil, 28.VIII.1979 Harmaja (H).

Norway. Sør-Trøndelag. Oppdal: fjeld Gjevilvasskam, between upper and lower Rensbekhjem, $1400 \mathrm{~m}$, 13.VIII.1951 Stordal 6148 (TRH). - Nordland. Beiarn: fjeld Bukkhaugen, 19.VIII.1967 Sivertsen (TRH).

The above records are new, that from Finland being new to the country. The spores of Stordal 6148 are slightly smaller than usual. This specimen was not included in Dissing (1966). The specimen from Sivertsen consists of several broken apothecia but I could not find any fully mature spores. Characters untypical of the species are the more or less distinct layer with features of textura angularis present in places between the $t$. intricata and $t$. prismatica, and the abundance of colourless hyphae in the $t$. prismatica warts on the exterior of the apothecium near the cup margin.

\section{Type studies}

Some names meant to refer to Helvella s. lato are missing in Dissing (1966), among them Acetabula murina Zeller and Paxina recurvum Snyder. Moreover, Pfister (1977) recently stated that Peziza verruculosa Berk. \& Curt. represents a Helvella. P. recurvum and $P$. verruculosa were considered valid and transferred to Gyromitra Fr. and Helvella, respectively, by Harmaja (1978). P. recurvum is treated by Harmaja (1979), but comments on $P$. verruculosa and $A$. murina are presented below.

Acetabula murina Zeller, Mycologia 19: 139. 1927. (non Leptopodia murina Boud., Hist. class. Discomyc. d'Europe: 37. 1907.) - Lectotype (selected here) and isolectotype examined: U.S.A., Oregon, Corvallis, in garden, 10.IV.1925, coll. Gilkey, det. Zeller 6821 (NY - Herb. Zeller). - Two specimens (nos. 6821 and 6942) were cited in the protologue. It appears that neither of them has been 
selected for the lectotype earlier. However, the envelope of the specimen selected here, the smaller one, bears the annotation 'Type'. The other specimen is a duplicate. Specimen no. 6942 was not received from the Zeller Herbarium on my request for the type. Both the specimens examined correspond well with the protologue and are easily identified as $H$. solitaria Karst. (syn. H. queletii Bres.; see Harmaja 1977a). Seaver (1942) considered A. murina a synonym of Paxina platypodia (Boud.) Seav. This appears correct, since Dissing (1966) lists Cyathipodia platypodia Boud. as a synonym of $H$. queletii. Conclusion: Acetabula murina is a new synonym of Helvella solitaria.

Geopyxis verruculosa Sacc. [unintentional nomen novum], Sylloge fungorum 8: 68. 1889. - Helvella verruculosa (Sacc.) Harmaja, Karstenia 18: 57. 1978. - Peziza verruculosa Berk. \& Curt., Proc. Amer. Acad. Arts Sci. 4: 127. 1860 (illegitimate as later homonym: non Peziza verruculosa Weinm., Syll. plant. nov. 2: 111. 1827; nec Peziza verruculosa Berk. \& Broome, J. Linn. Soc. London 14: 105. 1875.). Isotype examined: U.S.S.R., Russian S.F.S.R., Magadan Obl., Chukotski Peninsula, Arakamchechene Island by the Bering Strait, stony hills, 11.VIII. ca. 1855 Wright, Herb. U.S. N. Pacif. Expl. Exped. no. 369 (FH). - This fungus from the Asian side of the Bering Strait was apparently totally forgotten until Pfister (1977) recently examined the isotype and identified it in a most satisfactory way as the 'arctic-alpine form of Helvella acetabulum' as described in Dissing (1966). As Pfister considers the FH specimen to be an isotype, the holotype is apparently deposited in Herb. Berkeley in Kew (K). The collecting data and morphological characters of the specimen correspond with the scanty information given in the protologue. Microscopic sections were made of tissue taken ca. $1-3 \mathrm{~mm}$ below the cup margin and mounted in Melzer's reagent. The ascus bases were found to be pleurorhynchous. The fungus proved to be very close to $H$. arctoalpina Harmaja and $H$. dryadophila Harmaja, arctic-alpine segregates of $H$. acetabulum (Harmaja 1977b). $H$. verruculosa (Sacc.) Harmaja differs from them in having (1) larger spores, which measure $(17.0-) 18.0-22.0 \times 11.5-14.0 \mu \mathrm{m}$; the size difference is especially distinct when submature spores (generally larger than ripe ones: Harmaja 1977b), lying in the asci, are compared, and (2) a proportion of apparently mature spores possessing somewhat attenuated ends, or tending to be subfusiform. $H$. verruculosa also differs from $H$. arctoalpina (1) in its textura prismatica, the outermost layer of the excipulum, which has somewhat larger cells with slightly thicker walls, (2) somewhat longer terminal cells in the paraphyses (ca. $45-75 \mu \mathrm{m}),(3)$ in the narrower and less distinct $t$. angularis layer in the excipulum, and (4) in the not infrequently subfusiform shape of the submature spores. $H$. verruculosa is separated from $H$. dryadophila (1) by the macroscopic appearance of the apothecium, which closely resembles that of $H$. arctoalpina (see Harmaja 1977b), (2) by the excipulum, which is also very similar to that of $H$. arctoalpina, (3) by the contents of the paraphyses, which are paler and homogeneous (likewise much as in $H$. arctoalpina), and (4) by the apparent presence of a fairly distinct layer of $t$. angularis in the excipulum. $H$. verruculosa is known only from the type collection.

Acknowledgements. I am very grateful to the Curators of the following herbaria for arranging loans from their collections: C, FH, NY, O, OULU, S, TRH, TROM, TUR, and UPS. Field work was performed at the biological stations of the Universities of Helsinki and Oulu. Financial support was received from the foundations 'Jenny ja Antti Wihurin rahasto' and 'Oskar Öflunds Stiftelse'. Mr. Mauri Korhonen took the excellent photographs.

\section{References}

Ahti, T., Hämet-Ahti, L. \& Jalas, J. 1968: Vegetation zones and their sections in northwestern Europe. Ann. Bot. Fennici 5: 169-211.

Dähncke, R.M. \& Dähncke, S.M. 1979: 700 Pilze in Farbfotos. - 686 pp. Aarau.

Dissing, H. 1966: The genus Helvella in Europe with special emphasis on the species found in Norden. - Dansk Bot. Ark. 25: $1-172$.

Eckblad, F.-E. 1968: The genera of the operculate Discomycetes. A re-evaluation of their taxonomy, phylogeny and nomenclature. - Nytt Mag. Bot. 15: $1-191$.

Harmaja, H. 1974: Tarzetta pusilla n. sp. and T. spurcata (Pers.) n. comb. from Finland. - Karstenia 14: $116-120$.

-'-1976a: Two new species of agarics from northern Fennoscandia: Clitocybe montana and Lactarius lapponicus. - Karstenia 15: 19-22.

-"- 1976b: Hygrophorus pacificus (new for Europe) and H. hyacinthinus (new for northern Europe) found in Kuusamo, northern Finland. - Karstenia 15: 25-28.

-"-1976c: New species and combinations in the genera Gyromitra, Helvella and Otidea. - Karstenia 15: $29-32$.

-"- 1977a: A note on Helvella solitaria (syn. H. queletii) and H. confusa n. sp. - Karstenia 17: 40-44.

-"- 1977b: A revision of the Helvella acetabulum group (Pezizales) in Fennoscandia. - Karstenia 17: 45-58.

-'- 1977c: Leucoscypha ovilla n. comb., a species new to Europe, found in northern Finland. - Karstenia 17: $73-76$.

_"- 1978: New species and combinations in Helvella and Gyromitra. - Karstenia 18: 57. 
Harmaja, H. 1979: Notes on Gyromitra esculenta coll. and G. recurva, a noteworthy species of western North America. - Karstenia 19: 46-49.

Kallio, P. \& Kankainen, E. 1964: Notes on the macromycetes of Finnish Lapland and adjacent Finnmark. - Ann. Univ. Turku (A2) 32 (Rep. Kevo Subarct. Sta. 1): 178-235.

Lange, M. 1957: Macromycetes, part III. 1. Greenland Agaricales (pars), macromycetes caeteri. 2. Ecological and plant geographical studies. - Medd. Grønland
148(2): $1-125$

Pfister, D.H. 1977: Type studies in the genus Peziza: species described by Berkeley and Curtis from the United States North Pacific Exploring Expedition (1853-1856). Mycotaxon 6: 337-340.

von Schulmann, O. 1955: Pilzstudien in Finnland. Karstenia 3: 17-68.

Seaver, F.J. 1942 (reprint 1961): The North American cupfungi (operculates). - Suppl. ed. 377 pp., 74 pls. New York.

Accepted for publication

on November 20, 1979 